\title{
Additions and corrections for liverworts and hornworts of Singapore
}

\author{
Rui-Liang Zhu' ${ }^{1,2,}$, Chun-Hong Lu' and Lei Shu'
}

\begin{abstract}
Since the first record of liverworts and hornworts in Singapore was reported in 1845, the liverwort and hornwort flora of Singapore remain poorly known. Based on the examination on herbarium specimens kept in FH, GOET, SING, and SINU, as well as additional field collections, we found 12 liverworts new to Singapore. The occurrence of Caudalejeunea cristiloba and Jackiella javanica in Singapore is confirmed. Records of Lejeunea parva are erroneous because the voucher specimens from Singapore are assignable to Lejeunea cocoes. A total of 120 liverwort and hornwort species in 45 genera have thus far been recorded in Singapore, including 100 leafy liverworts, 12 simple thalloid liverworts, 5 complex thalloid liverworts, and 3 hornworts. The illustrations of Cheilolejeunea malaccensis, Drepanolejeunea vesiculosa, Jackiella javanica, J. singapurensis, and Lejeunea cocoes are provided.
\end{abstract}

KEYWORDS: Bryophyte Checklist, Hepaticae, Lejeuneaceae, new records, oil body

\section{INTRODUCTION}

Singapore is a small country located at the southern tip of Peninsular Malaysia and linked to the mainland by two causeways across the Straits of Johor. Owing to the limited original primary forests and the lack of higher mountains, the liverwort diversity of the country appears to be low. Since the first local liverwort, Lejeunea singaporensis Lindenb. [now known as Ceratolejeunea singapurensis (Lindenb.) Schiffn.], was recorded in Singapore by Gottsche et al. (1845), about 100 more species have been documented (Piippo et al., 2002; Furuki \& Tan, 2013).

In 2007, the esteemed teacher and distinguished bryologist, the late Dr. Benito C. Tan from the National University of Singapore and Singapore Botanical Gardens, invited the first author of the present paper to visit Singapore. During his stay in Singapore, the interesting liverwort collections in two local herbaria (SING, SINU) were examined and some fresh liverwort and hornwort samples were collected. In this paper, 12 new records were presented with brief notes on

${ }^{1}$ Bryology Laboratory, School of Life Sciences, East China Normal University, 500 Dongchuan Road, Shanghai 200241, China;

${ }^{2}$ Tiantong National Station of Forest Ecosystem, Shanghai Key Lab for Urban Ecological Processes and Eco-Restoration, East China Normal University, 500 Dongchuan Road, Shanghai 200241, China

*Corresponding author: rlzhu@bio.ecnu.edu.cn

Date Submitted: 03 September 2016

Date Accepted: 1 January 2017 morphology, distribution and habitat details. Several corrections and omissions for liverworts in Singapore were made.

\section{MATERIALS AND METHODS}

The herbarium collections from the herbaria $\mathrm{FH}$, GOET, HSNU, L, NY, SING and SINU were studied. Fresh samples used in this study were collected in Singapore in 2007 and 2008. All morphological and anatomical characters were examined using an Olympus BX43 microscope equipped with a DP71 digital camera. The nomenclature follows Söderström et al. (2016) as well as the most recent monographic studies.

\section{RESULTS}

Twelve species, marked with asterisks $\left(^{*}\right)$, are newly reported for Singapore. The existence of Caudalejeunea cristiloba, Drepanolejeunea vesiculosa and Jackiella javanica in Singapore is confirmed. Lejeunea parva is excluded from the liverwort flora of Singapore. The species names and collection data are listed below.

\section{Caudalejeunea cristiloba (Steph.) Gradst.}

Specimen examined: "pr. urbem, in horto botanico, ad arb. trunc. et viar. lat., ca. 20 m", 1930, F. Verdoorn s.n. (NY, SING).

Gradstein (1974) reported this species from Burma, Andaman, Thailand and Singapore. However, Piippo et al. (2002) did not see any specimens among the old and new 
collections during their study of Singapore liverwort flora. We found one epiphyllous specimen collected by F. Verdoorn in 1930 and kept in both SING and NY, which proved to be the true Caudalejeunea cristiloba.

\section{${ }^{*}$ Caudalejeunea recurvistipula (Gottsche) Schiffn.}

Specimen examined: Nee Soon Stream, ca. $210 \mathrm{ft}, 01^{\circ}$ 23'17.0" N., 10348'36.6" E., on tree trunks, 24 Jan. 2007, R.L. Zhu 20070124-2 (SING, HSNU).

Caudalejeunea is a common epiphyllous genus with a large-sized plant (Zhu \& So, 2001). The local plants of $C$. recurvistipula were found on tree trunks at Nee Soon Swamp. Recent molecular evidence showed that $C$. recurvistipula complex may be separated from $C$. reniloba (Gottsche) Steph. (Wang et al., 2016). In this study C. recurvistipula is provisionally adopted.

Oil bodies in local plants are 25-30 (-40) per cell, homogeneous, ovate to narrowly elliptical, 5-7.5 × 1-2 $\mu \mathrm{m}$.

\section{${ }^{*}$ Cheilolejeunea lindenbergii (Gottsche) Mizut.}

Specimen examined: No detailed collection data (NY).

Cheilolejeunea lindenbergii is characterized by the large underleaves slightly bilobed to almost entire, 5-keeled perianths, pycnolejeuneoid gynoecial innovation, strongly arched insertion of the underleaf, strongly mammillose lobe cells. Superficially, it may be confused with $C$. trifaria (Reinw., Blume et Nees) Mizut., but the latter differs in having bilobed underleaves (about 1/3 length).

\section{Cheilolejeunea malaccensis (G. Hoffm.) Xiao L. He}

Specimens examined: Pulau Tekong, on rubber trunk by sea, 22 Jan. 1978, Y.C. Wee (Wee Yeow Chin) W282 (SINU labeled as Pycnolejeunea sp.); ad arborum truncos secus vias et in horto botanico, 2-20 m, 4 Nov. 1893, Schiffner 2795 (Herb. Verdoorn 21055) (FH); Tree Top Walk, near the exit, on tree trunk, 8 Feb. 2007, R.-L. Zhu 20070208-1 (HSNU, SING); Pulau Ubin Island, Second growth evergreen tropical forest, on tree trunk, 8 Nov. 1998, A. Juslén 550 [SINU, Piippo et al. 2002 reported as Cheilolejeunea longiloba (Steph. ex G. Hoffm.) J.J. Engel \& B.C. Tan].

Cheilolejeunea malaccensis was recorded in Singapore (Hoffmann, 1935 as Pycnolejeunea malaccensis G. Hoffm.; $\mathrm{He}, 1996)$. It was described and illustrated by $\mathrm{He}$ (1996) who, however, failed to show the lobular apex of this species. Based on the type specimens in JE and $\mathrm{FH}$ and additional collections in Singapore, this species has the lobular apex connated with the leaf lobe usually by $2-4$ cells (Fig. 1G). This character also occurs in Cheilolejeunea ventricosa (Schiffn. ex P. Syd.) Xiao L. He and C. eximia (Jovet-Ast et Tixier) R.L. Zhu et M.L. So (Zhu \& So, 2001). The latter two species are easily separated from $C$. malaccensis by the long leaf lobules $(1 / 2-2 / 3$ as long as leaf lobes) and dioicous condition. Cheilolejeunea malaccensis has also been recorded in
Bangladesh, Laos, Malaysia (Tixier, 1970 as Pycnolejeunea malaccensis G. Hoffm.; He, 1996).

\section{Cheilolejeunea rigidula (Nees ex Mont.) R.M. Schust.}

Specimen examined: Lasia Valley, second growth evergreen tropical forest, 13 Nov. 1998, A. Juslén 665 (SINU, reported by Piippo et al., 2002 as Cheilolejeunea intertexta (Lindenb.) Steph.).

Cheilolejeunea rigidula was previously known as $C$. serpentina (Mitt.) Mizut. in pantropical regions. In tropical Asia this species usually occurs on tree trunks at low altitudes. Cheilolejeunea rigidula is similar to $C$. intertexta (Lindenb.) Steph., but differs in the dioicous sexuality, lejeuneoid gynoecial innovation and distinct trigones (Zhu et al., 2002). Cheilolejeunea rigidula was first recorded in Singapore by Mizutani (1963 as C. serpentina), however it was omitted in the earlier checklist by Piippo et al. (2002).

\section{*Cheilolejeunea vittata (Steph. ex G. Hoffm.) R.M. Schust. et Kachroo}

Specimens examined: Between Nee Soon Stream and Swamp, on decaying logs, 24 Jan. 2007, R.-L. Zhu 20070124-6A (HSNU, SING).

In Singapore Cheilolejeunea vittata may be confused with the common $C$. trapezia (Nees) Kachroo et R.M. Schust. The latter, however, differs in the absence of a vitta in the leaf lobe (Zhu et al., 2002).

Oil bodies in local plants are (1-) 2 per cell, coarsely segmented, $10-25 \times 6.5-10 \mu \mathrm{m}$.

\section{${ }^{*}$ Cololejeunea aequabilis (Sande Lac.) Schiffn.}

Specimens examined: Prope lacum, ca. $50 \mathrm{~m}$, epiphyllous, IV 1930, F. Verdoorn s.n. (SING).

Cololejeunea aequabilis is common in southeastern Asia (Zhu \& So, 2001 as C. yulensis (Steph.) Benedix; Zhu, 2005). Morphologically, C. aequabilis is easily confused with C. trichomanis (Gottsche) Besch. (Piippo et al., 2002 as C. goebelii (Gottsche ex Schiffn.) Schiffn.), but differs in its obcordate perianth always with two large, ear-like wings at apex and unicellular stylus.

\section{${ }^{*}$ Cololejeunea ceratilobula (P.C. Chen) R.M. Schust.}

Specimen examined: Bukit Timah, Fern valley, epiphyllous, 3 Feb. 2007, R.-L. Zhu 20070203-12 (HSNU, SING).

Cololejeunea ceratilobula is well characterized and readily separated from the local species of Cololejeunea by the whitish-green plants strongly appressed to the substrate, sigmoid marginal cells of leaf lobes, and narrowly triangular leaf lobules. In Singapore, C. ceratilobula is similar to $C$. planissima, but the latter has non-sigmoid marginal cells of leaf lobes. 

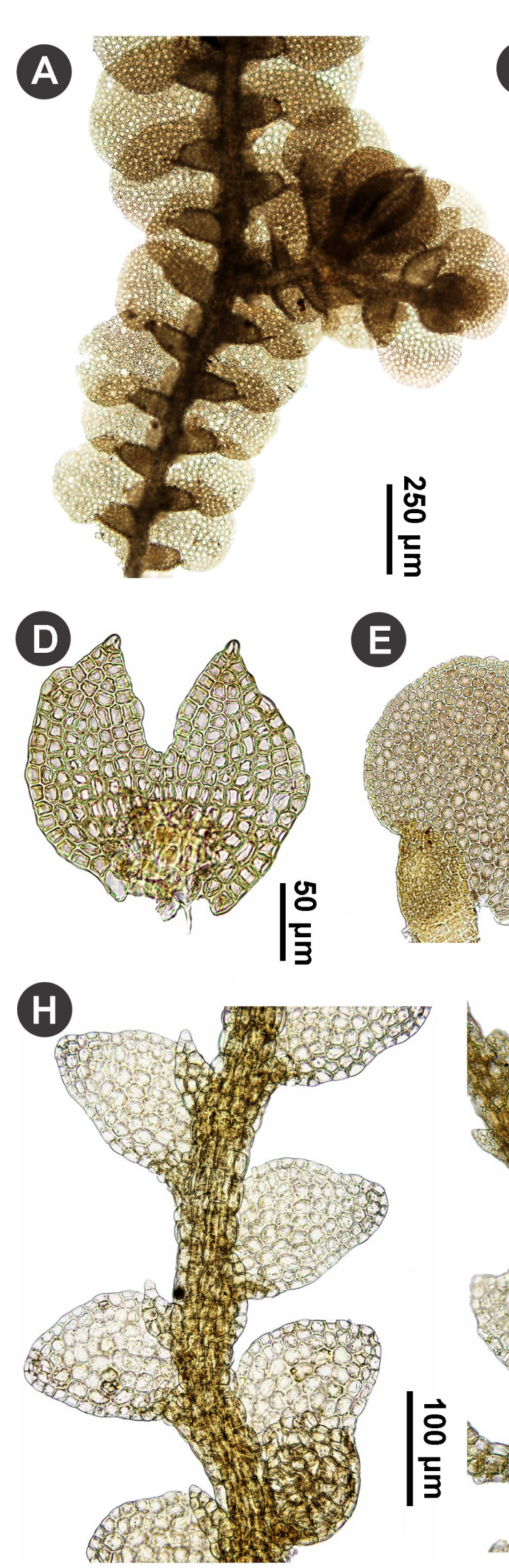
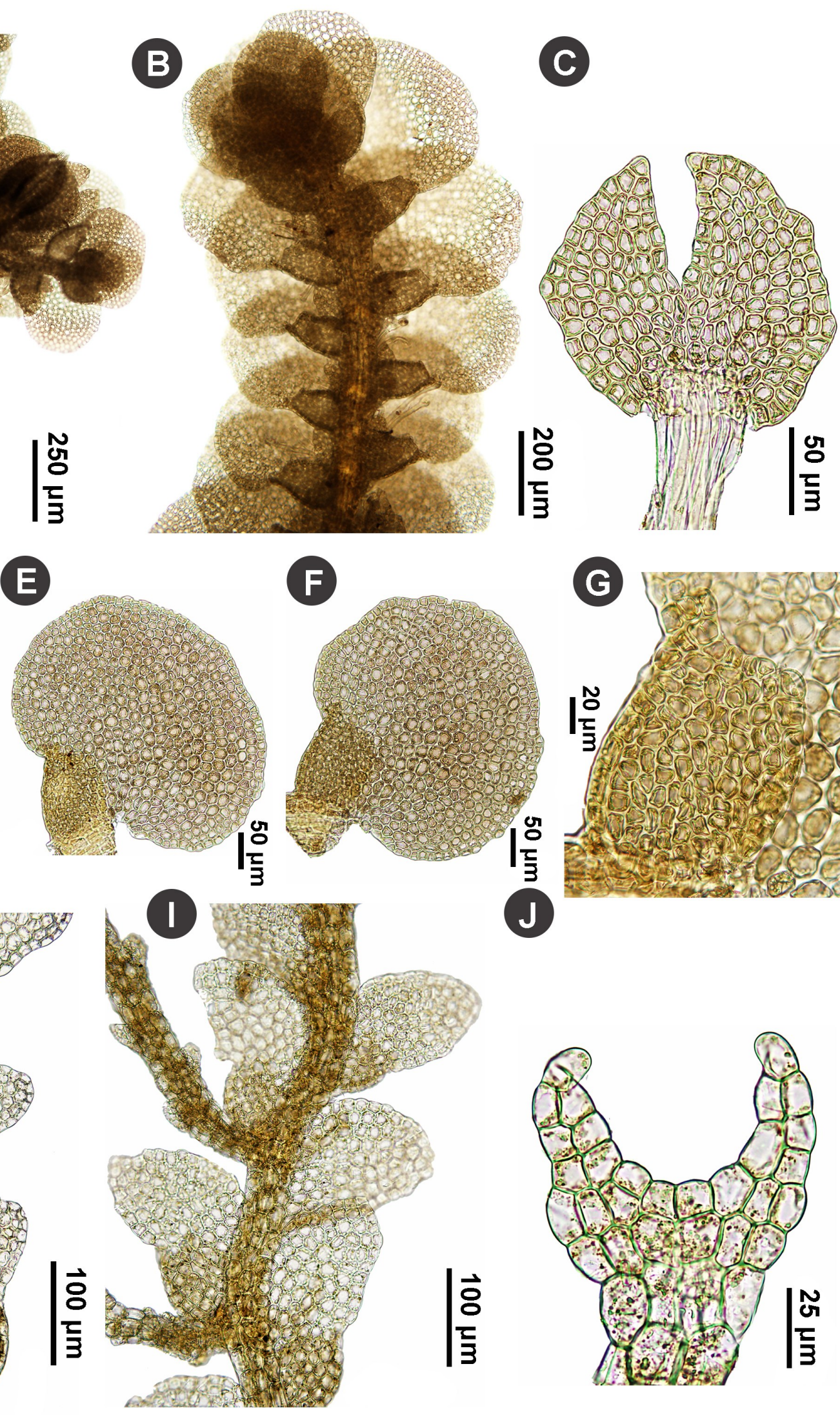

Figure 1. (A-G). Cheilolejeunea malaccensis (G. Hoffm.) Xiao L. He. A, B. Shoots, ventral view. C, D. Underleaves. E, F. Leaves, E, dorsal view, F, ventral view. G. Leaf lobule showing apex of leaf lobule. (H-J). Lejeunea cocoes Mitt. H, I. Shoots, $\mathrm{H}$, ventral view, I, dorsal view. J. Underleaf. A-G from R.-L. Zhu 20070208-1 (HSNU), H-J from R.-L. Zhu 20070207-2 (HSNU). 
${ }^{*}$ Cololejeunea grossepapillosa (Horik.) N. Kitag.

Specimen examined: Nee Soon Stream, 01 ${ }^{\circ} 23^{\prime} 7.0^{\prime \prime}$ N., $103^{\circ} 48^{\prime} 36.6^{\prime \prime}$ E., on tree trunks, 24 Jan. 2007, R.-L. Zhu 20070124-4C (HSNU, SING).

This species is one of most common epiphyllous species of Cololejeunea subg. Aphanolejeunea in southeastern Asia (Zhu \& So, 2001). In Singapore, it is found on tree trunks.

\section{${ }^{*}$ Cololejeunea planissima (Mitt.) Abeyw.}

Specimen examined: Pulau Ubin, Maman Beach, 01 ${ }^{\circ} 25^{\prime}$ $00.5^{\prime \prime}$ N., $103^{\circ} 58^{\prime} 29.1 "$ E., $2 \mathrm{~m}$, on tree trunks, 26 Jan. 2007 , R.-L. Zhu 20070126-11 (HSNU, SING)

Cololejeunea planissima is widespread in the Paleotropics but very rare in the Neotropics (Pócs et al., 2014).

\section{*Cololejeunea raduliloba Steph.}

Specimen examined: Pulau Ubin, Maman Beach, $01^{\circ}$ 25'00.5" N., 10358'29.1"E., $2 \mathrm{~m}$, on tree trunks, 26 Jan. 2007, R.-L. Zhu 20070126-18D (HSNU, SING).

Cololejeunea raduliloba is a pantropical species (Zhu \& So, 2001). It is widespread in Asia and in the Pacific, in Africa only on the Indian Ocean islands (Pócs, 2016).

\section{Drepanolejeunea vesiculosa (Mitt.) Steph.}

Specimens examined: Nee Soon Stream, 01 ${ }^{\circ} 23^{\prime} 17.0^{\prime \prime} \mathrm{N}$., $103^{\circ} 48^{\prime} 36.6^{\prime \prime E}$., on tree trunks, 24 Jan. 2007, R.-L. Zhu 20070124-4B (HSNU; SING as Drepanolejeunea ternatensis (Gottsche) Schiffn.); 12 March 1898, M. Flischer s.n. (Herb. E. Levier no. 123) (FH-Schiffner as $D$. singapurensis Schiffn.).

The record of $D$. vesiculosa in Singapore was accepted with doubt (Piippo et al., 2002). Drepanolejeunea vesiculosa is very similar to and easily confused with $D$. ternatensis (Gottsche) Schiffn. The two species share several characters including the minute size of plants, caducous leaves, narrow upright lobes of underleaves, ovate leaves with an acute or acuminate apex, and free lateral lobular margin proximal to the notch bordered by four rectangular cells. Drepanolejeunea vesiculosa, however, can be distinguished mainly by the lack of marginal teeth of leaves (Fig. 2).

\section{Jackiella javanica Schiffn.}

Specimens examined: Between Nee Soon Stream and Swamp, on soil, R.-L. Zhu 20070124-12 (HSNU, SING)

Jackiella javanica was treated as a doubtful species in Singapore because no voucher specimens were available (Piippo et al., 2002). Locally we found a population in the locality mentioned above. Jackiella javanica is very similar to J. singapurensis Schiffn., a rare species known only from Malaysia (Penang) and Singapore (Kitagawa, 1969; Piippo et al., 2002). The main difference includes the apex of the leaf (acute in J. singapurensis, but obtuse in J. javanica) (Fig. 3).

Oil bodies in local plants are compound, spherical to elliptical, 1(-2) per leaf cell, (7.5-) 10-20 × 7.5-10 $\mu \mathrm{m}$.

\section{Lejeunea cocoes Mitt.}

Specimens examined: Botanical Gardens, on tree trunks, 2 Feb. 2007, R.-L. Zhu 20070207-2 (HSNU, SING); Pulau Ubin, Maman Beach, 01²5'00.5" N., 10358'29.1" E., $2 \mathrm{~m}$, on tree trunks, 26 Jan. 2007, R.-L. Zhu 20070126-13 (HSNU, SING); Botanical Gardens, 6 Nov. 1998, A. Juslén 514 (SINU, reported by Piippo et al., 2002 as Lejeunea parva); ibid., 14 Nov. 1998, A. Juslén 698 (SINU, reported by Piippo et al., 2002 as L. parva); Pulau Ubin island, 8 Nov. 1998, A. Juslén 514 (SINU, reported by Piippo et al., 2002 as L. parva); Sungei Buloh Nature Reserve, 11 Nov. 1998, A. Juslén 627 (SINU, reported by Piippo et al., 2002 as L. parva); Bukit Batoh Park, 15 Nov. 1998, A. Juslén 709 (SINU; reported by Piippo et al., 2002 as L. parva); Sungei Buloh Nature Park, 11 Nov. 1998, A. Juslén 630 (SINU, reported by Piippo et al., 2002 as L. parva).

Lejeunea cocoes is one of the most common liverworts in Singapore. The local specimens previously determined as L. parva (S. Hatt.) Mizut. are assignable to L. cocoes. Lejeunea cocoes is known in tropical Asia (Lee, 2013). It is easily recognized by the minute plants, dioecy, strongly or slightly caducous leaves, large leaf cells, obtuse to obtuserounded apex of leaf lobe, and lanceolate lobes of underleaf (Zhu \& So, 2001) (Fig. 1H-J). In Singapore, L. cocoes resembles $L$. exilis in the small size, remote underleaves, and usually narrow lobes of underleaves. The latter, however, differs in the dimorphic underleaves (bilobed and subulate-ovate), usually eplicate perianths, and non caducous leaves (Zhu \& Grolle, 2003).

Oil bodies in local plants are 4-7 per cell, finely granular, subspherical to elliptical, $2.5-7.5 \times 1.5-2.7 \mu \mathrm{m}$.

\section{*Lejeunea exilis (Reinw., Blume et Nees) Grolle}

Specimens examined: Pulau Ubin, Kampong Surau, on tree trunks, 26 Jan. 2007, R.-L. Zhu 20070126-4B (HSNU); Botanical Gardens, on bark, ca. 50 m, 23 Oct. 1974, $H$. Sipman 6881 p.p. (GOET).

Lejeunea exilis is characterized by very minute plants, bilobed or subulate-ovate underleaves, acute to apiculate leaf apices of the leaf in well-developed plants, asexual reproduction usually by means of ribbon-like, marginal regenerants, cylindrical perianths usually without keels, and non caducous leaves. It is widespread in tropical Asia and Oceania (Zhu \& Grolle, 2003).

\section{*Lejeunea papilionacea Prantl}

Specimens examined: Upper Pierce Canal, $1^{\circ} 22^{\prime} 51.5^{\prime \prime}$ N., 103'48'54.3" E., on tree trunks, 24 Jan. 2007, R.-L. Zhu 20070124-11A (HSNU, SING); Bukit Timah, on fern stem, 3 Feb. 2007, R.-L. Zhu 20070203-13 (HSNU, SING).

Lejeunea papilionacea is readily confused with the Asiatic and Oceanic L. anisophylla Mont., but differs in 

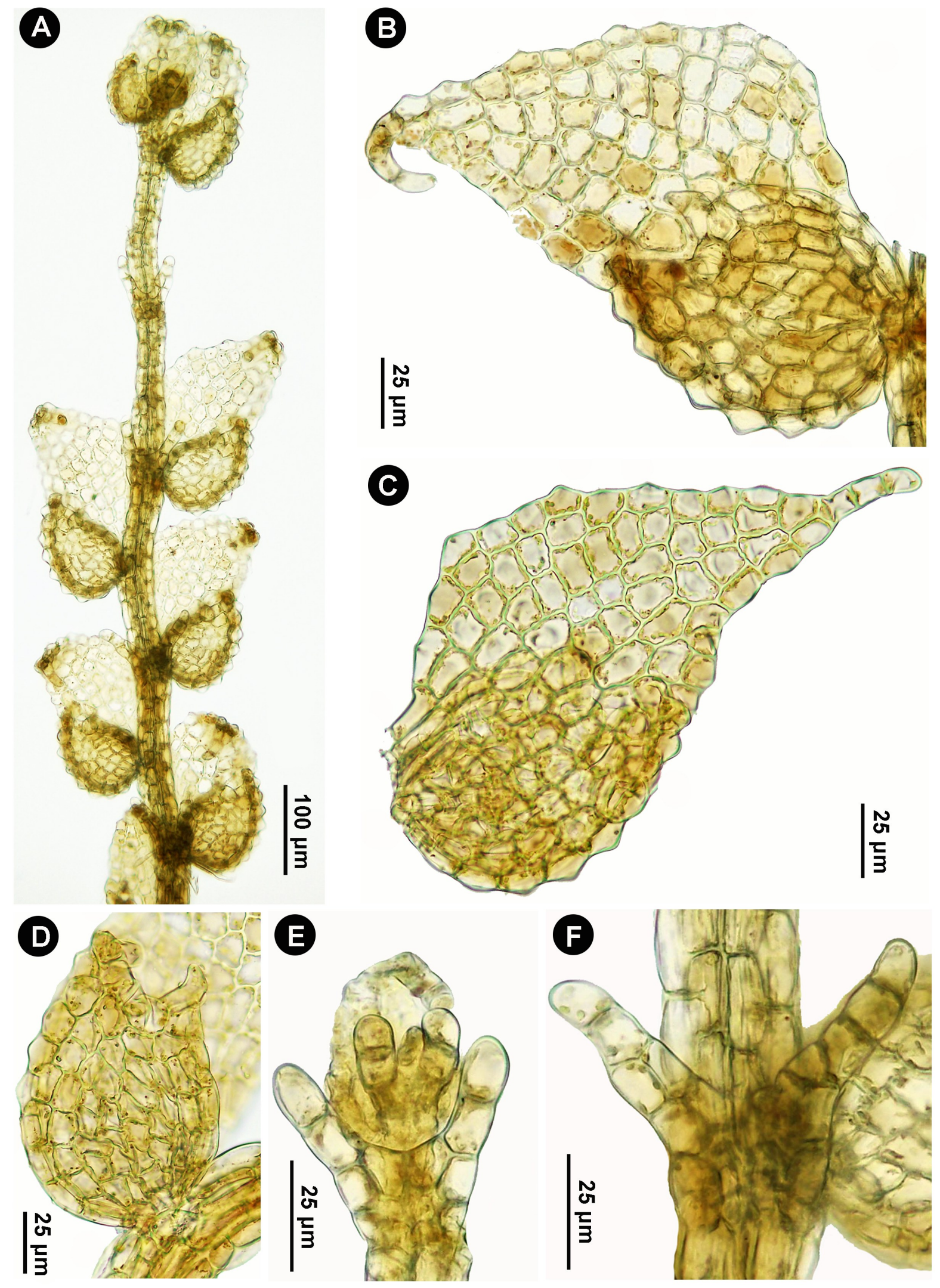

Figure 2. (A-F). Drepanolejeunea vesiculosa (Mitt.) Steph. A. Shoot showing caducous leaves, ventral view. B-C. Leaves, B, ventral view, $\mathrm{C}$, dorsal view. D. Leaf lobule, ventral view. E, Underleaf on branch. $\mathrm{F}$, Underleaf on main stem. A-F from $R$. $-L$. Zhu 20070124-4B(HSNU). 
Philippine Journal of Systematic Biology | Zhu, R.-L. et al: Liverworts and hornworts of Singapore
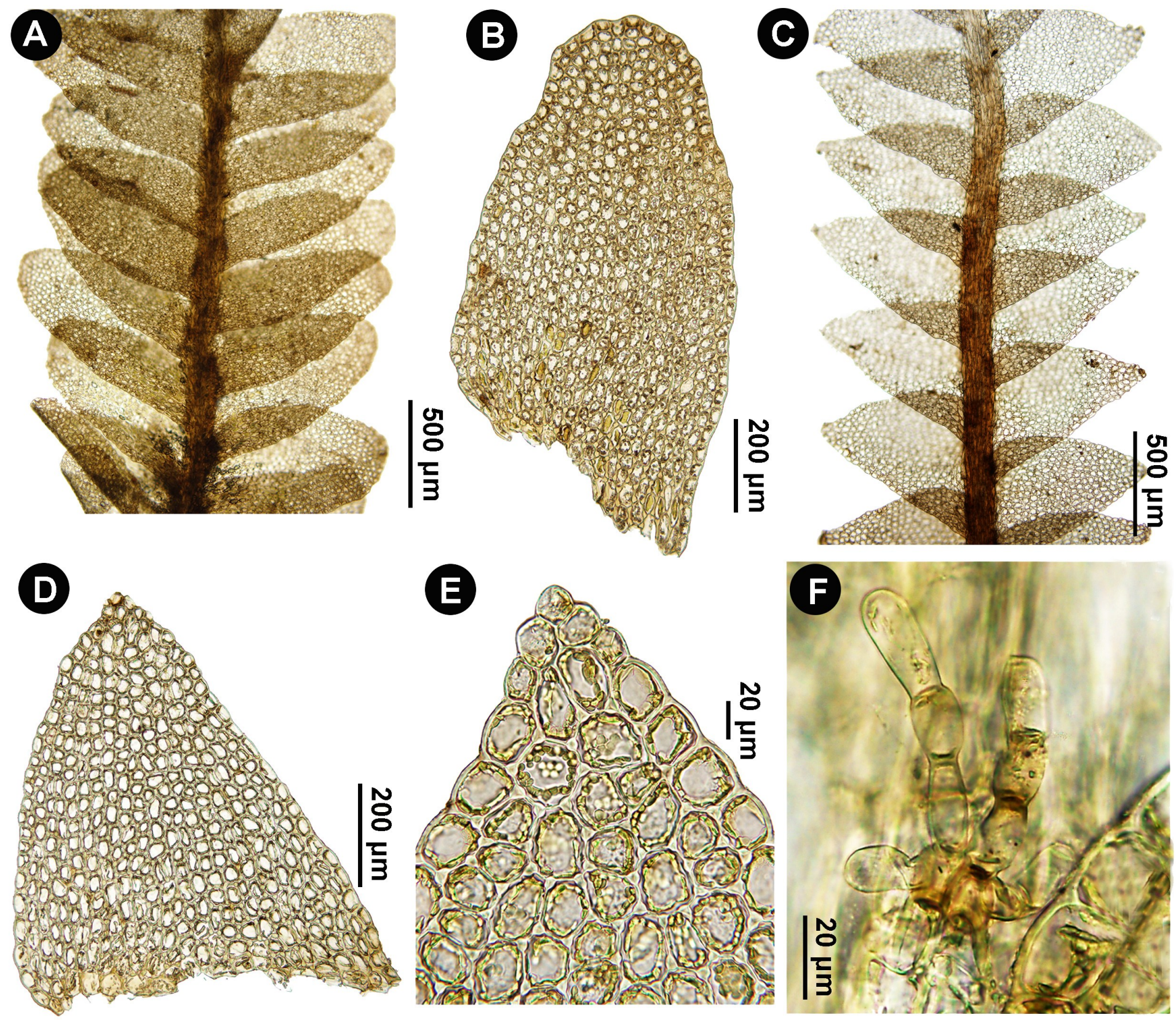

Figure 3. (A-B). Jackiella javanica Schiffn. A, shoot, dorsal view, B, leaf. (C-F). Jackiella singapurensis Schiffn. C, shoot, dorsal view. D, leaf. E, apex of leaf. F, underleaf. A-B from R.-L. Zhu 20070124-12 (HSNU), C-F from A. Juslén 719 (SINU). 
having obcordate perianths with 2-winged, auriculate lateral keels (Zhu \& Grolle, 2001).

Oil bodies in local plants are 4-15 per cell, compound, spherical or elliptical, $3.75-7.5 \times 2.5-5 \mu \mathrm{m}$.

\section{Leptolejeunea epiphylla (Mitt.) Steph.}

Specimen examined: Bukit Timah, in silvis primig., in decl. et in cacumine, ca. 200 m, April 1930, F. Verdoorn 13 (SING).

Leptolejeunea epiphylla is a pantropical epiphyllous species. It is very common in lowland forests in tropical Asia. The record of this species in Singapore by Herzog (1942) was omitted in Piippo et al. (2002).

\section{*Leptolejeunea maculata (Mitt.) Schiffn.}

Specimen examined: Swamp forest, fresh water, epiphyllous, Nov. 1933, E. J. Holttum s.n. (NY). Oceania.

Leptolejeunea maculata is common in tropical Asia and

\section{Schiffneriolejeunea pulopenangensis (Gottsche) Gradst.}

Specimens examined: Botanical Gardens, 01¹8'32.94" N., $103^{\circ} 49^{\prime} 07.53^{\prime \prime}$ E., on tree trunks, 2 March 2008, R.-L. Zhu 20080302-7 (HSNU); ibid., 01¹8'32.97" N., 10349'07.61"E., on tree trunks, 28 Jan. 2008, R.-L. Zhu 20080228-1b (HSNU).

Piippo et al. (2002) listed 21 out of the 74 species of Singapore liverworts which had no recent collections. They concluded that "these species may have become extinct locally due to heavy urbanization in the past 100 years". Schiffneriolejeunea pulopenangensis, a larger plant in Lejeuneaceae, is one of 21 examples. Our collections from the Singapore Botanical Gardens in 2008 led to the recovery of the missing species.

\section{*Spruceanthus planiusculus (Mitt.) X.Q. Shi, R.L. Zhu et Gradst.}

Specimen examined. No detailed locality, Feb. 1952, $R$. v.d. Wijk 80 (L-0486240).

Spruceanthus planiusculus is very common in tropical Asia. It was previously known as Archilejeunea planiuscula (Mitt.) Steph. (Shi et al., 2015).

\section{DISCUSSION}

The liverwort and hornwort flora of Singapore had been poorly known until the late Dr. Benito C. Tan, a well-known bryologist, initiated bryological work at the National University of Singapore. Benito greatly influenced the exploration of local liverwort and hornwort diversity. He organized many field trips and made the most comprehensive investigation of local liverworts and hornworts (Juslén et al., 2001; Piippo et al., 2002; Furuki \& Tan, 2013). The present paper adds 12 new records of leafy liverworts. The total number of liverwort and hornwort species is 120 in 45 genera (for details, see appendix). Almost half of them (59 spp.) belong to Lejeuneaceae, a family with rich diversity in tropical lowland rainforests (Zhu et al., 2017). Although most areas of Singapore are becoming more and more urbanized, and owing to the minute size of liverworts and hornworts and their difficult identification, the number of species, however, will be surely higher when extensive collections and monographic work are finished. It is delightful that a new Project-'Bryoflora of Singapore' is in progress. Undoubtedly, such projects are important for revealing the diversity of liverworts and hornworts especially in fast changing environments.

\section{ACKNOWLEDGEMENTS}

We would like to thank the curators and staff of $\mathrm{FH}, \mathrm{GOET}$, HSNU, L, NY, SING and SING for making specimens available for study through loans or visits. The first author (R. -L. Zhu) is grateful to the Research Fellowship of Singapore Botanical Gardens for supporting his visit to Singapore in 2007, to the late Benito C. Tan for field assistance and advice, to D. H. Murphy of the National University of Singapore for field assistance, and to Boon Chuan Ho of the Singapore Botanical Gardens for various help. This research was sponsored by the National Natural Science Foundation of China (nos. 31570206 and 31770224).

\section{LITERATURE CITED}

Furuki, T. \& B.C. Tan. 2013., Taxonomical studies of the family Aneuraceae (Marchantiophyta) of Singapore. Natural History Research, 12(2): 71-79.

Gottsche, C.M., J.B.G. Lindenberg \& C.G. Nees von Esenbeck., 1844-1847: Synopsis Hepaticarum, I-XXVI, 1 -834. Sumtibus Meissnerianis, Hamburg.

Gradstein, S.R. 1974., Studies on Lejeuneaceae subfam. Ptychanthoideae (Hepaticae). II: Two remarkable species of Caudalejeunea: C. grolleana spec. nov. and C. cristiloba (Steph.) comb. nov. Acta Botanica Neerlandica, 23: 333-343.

Hattori, S. \& O. Thaithong., 1978. Mrs. Ruth D. Svihla's Frullania collection in India, Burma, and Singapore. Bulletin of the National Science Museum, Tokyo. Series B, Botany, 4(2): 65-69.

He, X.L., 1996. Type studies on Pycnolejeunea (Lejeuneaceae, Hepaticae), III. Two Asiatic species described by Hoffmann. Annales Botanici Fennici, 33(1): 59-64.

Herzog, T., 1942., Revision der Lebermoosgattung Leptolejeunea Spr. in der Indomalaya. Flora, 135: 377434.

Ho, B.-C., 2013., The liverwort genus Marchantia L. 
(Marchantiophyta: Marchantiopsida) in Singapore, with a new species record. Nature in Singapore, 6: 187-190.

Hoffmann, G. 1935. Monographische Studien über die indomalayischen Arten von Pycnolejeunea. Annales Bryologici, 8: 80-129.

Juslén, A., X.L. He, S. Piippo \& B.C. Tan., 2001. Oil bodies of hepatics from Singapore. Journal of the Hattori Botanical Laboratory, 91: 265-276.

Kitagawa, N. 1969., A small collection of Hepaticae from Penang, Malaysia. Bulletin of Nara University of Education Natural Science, 18(2): 27-43.

Lee, G.E. 2013.. A systematic revision of the genus Lejeunea Lib. (Marchantiophyta: Lejeuneaceae) in Malaysia. Cryptogamie Bryologie, 34(4): 381-484.

Mizutani, M. 1963.. On some Indian species of the family Lejeuneaceae described by W. Mitten. Journal of the Hattori Botanical Laboratory, 26: 171-184.

Piippo, S., X.L. He, A. Juslén, B.C. Tan, D.H. Murphy \& T. Pócs. 2002., Hepatic and hornwort flora of Singapore. Annales Botanici Fennici, 39(2): 101-127.

Pócs, T. 2016., Contribution to the bryoflora of Australia. VI. The genus Cololejeunea (Spruce) Steph. (Lejeuneaceae, Marchantiophyta). Polish Botanical Journal, 61(2): 205229.

Pócs, T., A. Bernecker \& P. Tixier., 2014. Synopsis and key to species of Neotropical Cololejeunea (Lejeuneaceae). Acta Botanica Hungarica, 56(1-2): 185-226.

Schiffner, V. 1898. Conspectus Hepaticarum Archipelagi Indici. Staatsdruckerei, Batavia, $382 \mathrm{pp}$.

Shi, X.-Q., S.R. Gradstein \& R.-L. Zhu., 2015. Phylogeny and taxonomy of Archilejeunea (Marchantiophyta: Lejeuneaceae) based on molecular markers and morphology. Taxon, 64(5): 881-892.

So, M. L. 2003., The genus Schistochila in Asia. Journal of the Hattori Botanical Laboratory, 93: 79-100.

Söderström, L., A. Hagborg, M. von Konrat, S. BartholomewBegan, D. Bell, L. Briscoe, E. Brown, D.C. Cargill, E.D. Cooper, D.P. Costa, B.J. Crandall-Stotler, G. Dauphin, J.J. Engel, K. Feldberg, D. Glenny, S.R. Gradstein, X. He, A.L. Ilkiu-Borges, J. Heinrichs, J. Hentschel, T. Katagiri, N.A. Konstantinova, J. Larrain, D.G. Long, M. Nebel, T. Pócs, F. Puche, E. Reiner-Drehwald, M.A.M. Renner, A. Sass-Gyarmati, A. Schäfer-Verwimp, J.G. Segarra Moragues, R.E. Stotler, P. Sukkharak, B.M. Thiers, J. Uribe, J. Váňa, J.C. Villarreal, M. Wigginton, L. Zhang \& R.-L. Zhu., 2016. World checklist of hornworts and liverworts. PhytoKeys, 59: 1-828.

Stephani, F. 1890., Die Gattung Lejeunea im Herbarium Lindenberg (Fortsetzung). Hedwigia, 29 (2): 68-99.

Stephani, F. 1908., SpeciesHepaticarum 3 . Bulletin de I' Herbier Boissier, (ser. 2) 8(10): 745-776.

Stephani, F., 1922. Species Hepaticarum 6. George \& Cie,
Genève \& Bale, 241-368.

Svihla, R.D., 1959. The female inflorescence of Frullania picta. The Bryologist, 62(3): 193-195.

Tixier, P. 1970., Bryophytae Indosinicae. Bryophytes du Laos méridional (Paksé et Bolovens). Annales de la Faculté des Sciences, Université de Phnom Penh, 3: 153 -172 .

Wang, J., R.-L. Zhu \& S.R. Gradstein., 2016. Taxonomic revision of Lejeuneaceae subfamily Ptychanthoideae (Marchantiophyta) in China. Bryophytorum Bibliotheca, 65: 1-141.

Zheng, M. \& R.-L. Zhu., 2009. Karyological studies on some species of Radula (Radulaceae, Jungermanniopsida, Marchantiophyta). Nova Hedwigia, 88(1-2): 229-244.

Zheng, M. \& R.-L. Zhu. 2010. Karyological observations on Lejeuneaceae. The Bryologist, 113(3): 605-618.

Zhu, R.-L. 2005., Cololejeunea aequabilis (Sande Lac.) Schiffn. (Jungermanniopsida: Lejeuneaceae), the correct name for Cololejeunea yulensis (Steph.) Benedix. Journal of Bryology, 27(4): 357-360.

Zhu, R.-L. 2006., On Cheilolejeunea tenella (Taylor) J.J. Engel \& B.C. Tan (Jungermanniopsida: Lejeuneaceae), a poorly known species from Singapore. Annales Botanici Fennici, 43(6): 484-487

Zhu, R.-L. \& R. Grolle., 2001. Notes on the taxonomy and distribution of Acanthocoleus yoshinaganus and Lejeunea papilionacea (Hepaticae, Lejeuneaceae). Annales Botanici Fennici, 38(4): 329-336.

Zhu, R.-L. \& R. Grolle. 2003. Taxonomy and distribution of Lejeunea exilis (Lejeuneaceae, Hepaticae). Annales Botanici Fennici, 40(2): 101-106.

Zhu, R.-L. \& M.L. So., 2001. Epiphyllous liverworts of China. Nova Hedwigia Beiheft, 121: 1-418.

Zhu, R.-L., M.L. So \& Y.-F. Wang., 2002. The genus Cheilolejeunea (Hepaticae, Lejeuneaceae) in China. Nova Hedwigia, 75(3-4): 387-408.

Zhu, R.-L., L. Shu, A.M.A. Mustapeng \& M. Suleiman., 2017. Thiersianthus (Marchantiophyta: Lejeuneaceae), a new genus from lowland rainforests in Borneo. The Bryologist, 120(4): 511-520. 
Appendix: The updated checklist of liverworts and hornworts in Singapore.

An alphabetical list of the known taxa of liverworts and hornworts in Singapore is presented, comprising 100 leafy liverworts, 12 simple thalloid liverworts, 5 complex thalloid liverworts, and 3 hornworts. Invalid names are not included. For saving space, bibliographic references are only given for records not listed by Piippo et al. (2002). Chiloscyphus tridens Steph. (Stephani, 1922), a poorly known species from Singapore, is not included in the present checklist because it may be a synonym of the common Heteroscyphus in Singapore.

1. Acrolejeunea fertilis (Reinw., Blume et Nees) Schiffn.

2. Acrolejeunea pycnoclada (Taylor) Schiffn.

3. Acrolejeunea securifolia (Nees) Steph.

4. Acromastigum echinatum (Gottsche) A. Evans

5. Acromastigum inaequilaterum (Lehm. et Lindenb.) A. Evans

6. Aneura blasioides (Horik.) Furuki (Furuki \& Tan, 2013)

7. Aneura pinguis (L.) Dumort.

8. Bazzania fleischeri (Steph.) Abeyw. (Stephani, 1908 as Mastigobryum fleischeri Steph.)

9. Bazzania indica (Gottsche et Lindenb.) Trevis. (Schiffner, 1898)

10. Bazzania paradoxa (Sande Lac.) Steph.

11. Bazzania recurva (Mont.) Trevis.

12. Bazzania tridens (Reinw., Blume et Nees) Trevis.

13. Bazzania wallichiana (Lindenb.) Trevis.

14. Blepharostoma trichophyllum (L.) Dumort.

15. Calypogeia arguta Nees et Mont.

16. Caudalejeunea cristiloba (Steph.) Gradst. (Piippo et al., 2002; present study)

17. Caudalejeunea recurvistipula (Gottsche) Schiffn. (Zheng \& Zhu, 2010; present study)

18. Ceratolejeunea singapurensis (Lindenb.) Schiffn.

19. Cheilolejeunea intertexta (Lindenb.) Steph.

20. Cheilolejeunea lindenbergii (Gottsche) Mizut. (present study)

21. Cheilolejeunea malaccensis (G. Hoffm.) Xiao L. He (Hoffmann, 1935 as Pycnolejeunea malaccensis G. Hoffm.; He, 1996; present study)

22. Cheilolejeunea rigidula (Nees ex Mont.) R.M. Schust. (Mizutani 1963 as Cheilolejeunea serpentina (Mitt.) Steph.; present study)

23. Cheilolejeunea trapezia (Nees) Kachroo et R.M. Schust. (Piippo et al., 2002 as Cheilolejeunea longiloba (Steph. ex G. Hoffm.) J.J. Engel \& B.C. Tan)

24. Cheilolejeunea vittata (Steph. ex G. Hoffm.) R.M. Schust. \& Kachroo (present study)

25. Cheilolejeunea ventricosa (Schiffn. ex P. Syd.) Xiao L. He 26. Cololejeunea aequabilis (Sande Lac.) Schiffn. (present study)

27. Cololejeunea ceratilobula (P.C. Chen) R.M. Schust. (present study)

28. Cololejeunea cordiflora Steph.

29. Cololejeunea cuneata (Lehm. et Lindenb.) Herzog

30. Cololejeunea floccosa (Lehm. et Lindenb.) Schiffn.

31. Cololejeunea grossepapillosa (Horik.) N. Kitag. (present study)

32. Cololejeunea haskarliana (Lehm.) Schiffn.

33. Cololejeunea inflectens (Mitt.) Benedix

34. Cololejeunea planissima (Mitt.) Abeyw. (present study)

35. Cololejeunea raduliloba Steph. (present study)

36. Cololejeunea siamensis Steph. (Piippo et al., 2002 as Cololejeunea pluripunctata Benedix)

37. Cololejeunea stoniana Tixier

38. Cololejeunea trichomanis (Gottsche) Besch. (Piippo et al., 2002 as Cololejeunea goebelii (Gottsche ex Schiffn.) Schiffn.)

39. Cololejeunea wightii Steph.

40. Cyathodium sp.

41. Cylindrocolea kiaeri (Austin) Váňa (Piippo et al., 2002 as Cephaloziella kiaeri (Austin) Douin)

42. Drepanolejeunea vesiculosa (Mitt.) Steph. (present study)

43. Folioceros glandulosus (Lehm. et Lindenb.) D.C. Bharadwaj

44. Frullania apiculata (Reinw., Blume et Nees) Nees

45. Frullania brotheri Steph.

46. Frullania ericoides (Nees) Mont.

47. Frullania gaudichaudii (Nees et Mont.) Nees et Mont.

48. Frullania gracilis (Reinw., Blume et Nees) Nees (Svihla, 1959 as Frullania picta Steph.; Hattori \& Thaithong, 1978)

49. Frullania hypoleuca Nees

50. Frullania intermedia (Reinw., Blume et Nees) Nees

51. Frullania nodulosa (Reinw., Blume et Nees) Nees

52. Frullania sublignosa Steph.

53. Heteroscyphus argutus (Reinw., Blume et Nees) Schiffn.

54. Heteroscyphus splendens (Lehm. et Lindenb.) Grolle

55. Heteroscyphus succulentus (Gottsche) Schiffn.

56. Heteroscyphus zollingeri (Gottsche) Schiffn.

57. Jackiella javanica Schiffn. (Piippo et al., 2002; present study)

58. Jackiella singapurensis Schiffn.

59. Kurzia gonyotricha (Sande Lac.) Grolle

60. Lejeunea anisophylla Mont. (Piippo et al. 2002 as Lejeunea catanduana (Steph.) H.A. Mill., Bonner et Bischl.)

61. Lejeunea cocoes Mitt. (Lee, 2013; present study)

62. Lejeunea exilis (Reinw., Blume et Nees) Grolle (present study)

63. Lejeunea flava (Sw.) Nees

64. Lejeunea papilionacea Prantl (present study) 
65. Lejeunea sordida (Nees) Nees (Lee, 2013)

66. Lejeunea tenella Taylor (Piippo et al., 2002 as Cheilolejeunea tenella (Taylor) Engel \& B.C.Tan; Zhu, 2006)

67. Lepidolejeunea bidentula (Steph.) R.M. Schust.

68. Lepidolejeunea borneensis (Steph.) R.M. Schust.

69. Leptolejeunea elliptica (Lehm. et Lindenb.) Besch.

70. Leptolejeunea epiphylla (Mitt.) Steph. (present study)

71. Leptolejeunea maculata (Mitt.) Schiffn. (present study)

72. Leptolejeunea vitrea (Nees) Schiffn. (Herzog, 1942)

73. Lopholejeunea nigricans (Lindenb.) Schiffn.

74. Lopholejeunea subfusca (Nees) Schiffn.

75. Marchantia acaulis Steph.

76. Marchantia emarginata Reinw., Blume et Nees (Ho, 2013)

77. Metalejeunea cucullata (Reinw., Blume et Nees) Grolle (Stephani, 1890 as Lejeunea cucullata (Reinw., Blume et Nees) Nees)

78. Microlejeunea filicuspis (Steph.) Heinrichs, Schäf.-Verw., Pócs et S. Dong (Piippo et al., 2002 as Harpalejeunea filicuspis (Steph.) Mizut.)

79. Microlejeunea lunulatiloba Horik. (Miller et al., 1983; Piippo et al., 2002)

80. Microlejeunea punctiformis (Taylor) Steph.

81. Microlejeunea ulicina (Taylor) Steph.

82. Myriocoleopsis minutissima (Sm.) R.L.Zhu, Y.Yu et Pócs (Piippo et al., 2002 as Cololejeunea minutissima (Sm.) Steph.)

83. Neolepidozia mamillosa (Schiffn.) E.D. Cooper (Piippo et al., 2002 as Lepidozia mamillosa Schiffn.)

84. Neolepidozia wallichiana (Gottsche) Fulford et J. Taylor (Piippo et al., 2002 as Lepidozia wallichiana Gottsche)

85. Notothylas javanica (Sande Lac.) Gottsche

86. Pallavicinia levieriSchiffn.

87. Pallavicinia lyellii (Hook.) Gray

88. Phaeoceros laevis (L.) Prosk.

89. Plagiochila bantamensis (Reinw., Blume et Nees) Mont.

90. Plagiochila kurzii Steph.

91. Plagiochila sciophila Nees

92. Podomitrium malaccense (Steph.) Campb.

93. Pycnolejeunea contigua (Nees) Grolle

94. Radula anceps Sande Lac.

95. Radula amoena Herzog (Zheng \& Zhu, 2009)

96. Radula borneensis Steph.

97. Radula reflexa Nees et Mont.

98. Riccardia crenulata Schiffn. (Furuki \& Tan, 2013)

99. Riccardia elata (Steph.) Schiffn. (Furuki \& Tan, 2013)

100. Riccardia graeffei (Steph.) Hewson

101. Riccardia grossitexta (Steph.) Furuki (Furuki \& Tan, 2013)

102. Riccardia latifrondoides Schiffn. (Furuki \& Tan, 2013)

103. Riccardia singapurensis Schiffn. (Furuki \& Tan, 2013)

104. Riccardia tenuicostata Schiffn.

105. Riccia treubiana Steph.
106. Schiffneriolejeunea cumingiana (Mont.) Gradst.

107. Schiffneriolejeunea pulopenangensis (Gottsche) Gradst.

(Piippo et al., 2002; present study)

108. Schiffneriolejeunea tumida (Nees) Gradst.

109. Schistochila sciurea (Nees) Schiffn. (So, 2003)

110. Solenostoma ariadne (Taylor) R.M. Schust. ex Váňa et

D.G. Long (Piippo et al., 2002 as Jungermannia ariadne Taylor)

111. Solenostoma truncatum (Nees) R.M. Schust. ex Váňa et D.G.Long (Piippo et al., 2002 as Jungermannia truncata Nees)

112. Spruceanthus planiusculus (Mitt.) X.Q. Shi, R.L. Zhu \& Gradst. (present study)

113. Telaranea major (Herzog) J.J. Engel et G.L. Merr.

(Piippo et al., 2002 as Arachniopsis major Herzog)

114. Thysananthus comosus Lindenb.

115. Thysananthus fruticosus (Lindenb. et Gottsche) Schiffn.

(Piippo et al., 2002 as Dendrolejeunea fruticosa

(Lindenb. \& Gottsche) Lacout.)

116. Thysananthus humilis (Gottsche) Sukkharak et Gradst. (=Mastigolejeunea humilis (Gottsche) Schiffn.; Piippo et al., 2002 as Mastigolejeunea auriculata (Wilson et Hook.) Steph.)

117. Thysananthus spathulistipus (Reinw., Blume et Nees) Lindenb.

118. Trichocolea pluma (Reinw., Blume et Nees) Mont.

119. Tricholepidozia neesii (Lindenb.) E.D. Cooper (Piippo et al., 2002 as Telaranea neesii (Lindenb.) Fulford)

120. Wiesnerella denudata (Mitt.) Steph. 